\title{
Effects of Mulching with Accumulator Plants Straws on Nutrients Uptake of Cyphomandra betacea Seedlings under Cadmium Stress
}

\author{
Kewen Huang1,a, Liying Ouyang, ${ }^{2, b}$, Ming'an Liao ${ }^{1, c}$ and Lijin Lin ${ }^{3, d *}$ \\ ${ }^{1}$ College of Horticulture, Sichuan Agricultural University, Chengdu, Sichuan, China \\ ${ }^{2}$ Department of Modern Agriculture, Chendu Agricultural College, Chengdu, Sichuan, China \\ 3Institute of Pomology and Olericulture, Sichuan Agricultural University, Chengdu, Sichuan, China \\ a263733029@qq.com, b24983471@qq.com, Iman@sicau.edu.cn, dllj800924@qq.com \\ ${ }^{*}$ Corresponding author. Kewen Huang and Liying Ouyang contributed equally to this work.
}

Keywords: Cyphomandra betacea; Accumulator plant straw; Nutrients uptake; Cadmium stress

\begin{abstract}
A pot experiment was carried out to study the effects of mulching with four accumulator plants straws (Trifolium repens, Eclipta prostrate, Conyza canadensis, Stellaria media) on the total phosphorus and total potassium content in Cyphomandra betacea seedlings under cadmium stress. The results showed that all accumulator plants straws could improve the content of total phosphorus in $C$. betacea seedlings in varying degrees compared with the uncovered. And under cadmium stress, the total potassium content of roots in $C$. betacea seedlings was lower than uncovered by mulching with $T$. repens and $E$. prostrate straws. Other accumulator plants straws all increased the total potassium content of $C$. betacea seedlings compared with the uncovered. And in all parts of $C$. betacea seedlings, mulching with $S$. media straw maximized the total phosphorus and total potassium content in $C$. betacea seedlings. Therefore, mulching with $S$. media straw could significantly promote the nutrients uptake of $C$. betacea seedlings under cadmium stress.
\end{abstract}

\section{Introduction}

Due to the emission of industrial waste and the improper use of chemical fertilizers and pesticides, the orchards in the outskirts of the city have already faced the hazard of heavy metal pollution [1]. Cadmium $(\mathrm{Cd})$ is a high-residue and hard-to-degrade heavy metal that can easily cause plants metabolic disorder and affect the yield and quality of crops [2]. It has been found that when the content of $\mathrm{Cd}$ in the soil exceeds a certain limit, it will inhibit the absorption of nutrients by plants [3]. Returning straw to field is a commonly used measure for crops cultivation, which can improve soil structure, promote soil nutrients cycling and effectively increase the soil fertility to promote plants growth [4]. And the return of straw could also improve the utilization of soil nutrients by plants, which in turn increases the amount of plants nitrogen, phosphorus and potassium [5]. Some scholars have found that applying different accumulator plants straws to the Cd-contaminated soil could significantly increase the shoots biomass and leaves SPAD of Capsella bursa-pastoris, providing a new theory for plants growth under Cd stress [6]. Cyphomandra betacea is a perennial evergreen shrub of the genus Solanaceae, which combines ornamental and edible values with rich vitamins and beneficial trace elements [7]. However, with the intensification of Cd pollution in orchard soil, the growth of $C$. betacea is potentially threatened. Study has reported that planted $C$. betacea seedlings after mulching with four Cd-tolerant plants straws in Cd-contaminated soil could effectively increase the photosynthetic pigment content and antioxidant enzyme activity of $C$. betacea [8]. But studies on the nutrients uptake of $C$. betacea seedlings by mulching with accumulator plants straws in Cd-contaminated soil have not been reported. Therefore, the purpose of this study was to seek out the accumulator plants (Trifolium repens [9], Eclipta prostrate [10], Conyza canadensis [11], Stellaria media [12]) straws which could promote the nutrients uptake of C. betacea seedlings. 


\section{Materials and Methods}

Materials Collection. The shoots of four accumulator plants (T. repens, E. prostrate, C. Canadensis, $S$. media) and soil were collected from the farmland of Ya'an Campus of Sichuan Agricultural University (not polluted by $\mathrm{Cd}$ ) in June, 2014. And fixed all plants at $110^{\circ} \mathrm{C}$ for 15 minutes and dried at $80^{\circ} \mathrm{C}$ until they were weighed after washing them with deionized water. Then cut into small pieces of less than $1 \mathrm{~cm}$ by scissors and stored. The seeds of $C$. betacea were collected from three-years of fruitful $C$. betacea from the Ya'an Campus of Sichuan Agricultural University in October 2013. And the seeds of $C$. betacea were sowed in the sand plate in June 2014.

Experimental Design. The experiment was conducted in farm of Ya'an Campus of Sichuan Agricultural University. In June 2014, the unpolluted soil was air-dried and passed through a 5-mm sieve. $3 \mathrm{~kg}$ air-dried soil was weighed into each plastic pot $(15 \mathrm{~cm}$ high, $18 \mathrm{~cm}$ in diameter), soaking uniformly CdCl $2 \cdot 2.5 \mathrm{H} 2 \mathrm{O}$ by $10 \mathrm{mg} / \mathrm{kg}$ and balanced for 4 weeks. In July 2014, the straws of four accumulator plants were separately mulched in Cd-contaminated soil surface. Coverage was $6 \mathrm{~g}$ per pot and the water was kept moist and equilibrated for one week. Then, the same growth $C$. betacea with the four real leaves were transplanted into the pots. Two plants were planted in each pot. Five replicates per treatment and all pots were watered each day to keep the soil moisture about $80 \%$. The distance between pots was $15 \mathrm{~cm}$, and the pot position exchanged aperiodically to weaken the impact of the marginal effects. After 40 days, all $C$. betacea seedlings were harvested and divided, fixed all plants at $110^{\circ} \mathrm{C}$ for 15 minutes and dried at $80^{\circ} \mathrm{C}$ until they were weighed after washing them with deionized water. The total phosphorus content of $C$. betacea seedlings were determined by molybdenum antimony colorimetric method [13]. The total potassium content of $C$. betacea seedlings were determined by flame spectrophotometer [13].

Statistical Analyses. Statistical analyses were conducted using statistical software of SPSS 17.0. Data were analyzed by one-way ANOVA with least significant difference at $5 \%$ confidence level.

\section{Results and Discussion}

Total Phosphorus Content in $C$. betacea Seedlings. For the roots, stems, leaves and shoots of $C$. betacea seedlings, mulching with accumulator plants straws could increase its total phosphorus content in varying degrees compared to the uncovered (Table 1). The order of roots total phosphorus content in $C$. betacea seedlings from large to small was ranked: S. media, C. canadensis, $E$. prostrata, $T$. repens, uncovered. And mulching with $S$. media straw increased the total phosphorus content of the roots in $C$. betacea seedlings by $68.85 \%(P<0.05)$ compared with the uncovered. The order of stems total phosphorus content in $C$. betacea seedlings from large to small was ranked: $S$. media, C. canadensis, E. prostrata, T. repens, uncovered. And mulching with $S$. media straw increased the total phosphorus content of the stems in C. betacea seedlings by $188.83 \%$ $(P<0.05)$ compared with the uncovered. The order of leaves total phosphorus content in $C$. betacea seedlings from large to small was ranked: S. media, C. canadensis, E. prostrata, T. repens, uncovered. And mulching with $S$. media straw increased the total phosphorus content of the leaves in $C$. betacea seedlings by $72.12 \%(P<0.05)$ compared with the uncovered. The order of shoots total phosphorus content in $C$. betacea seedlings from large to small was ranked: $S$. media, $C$. canadensis, E. prostrata, T. repens, uncovered. And mulching with $S$. media straw increased the total phosphorus content of the shoots in $C$. betacea seedlings by $95.94 \%(P<0.05)$ compared with the uncovered.

Total potassium content in $\boldsymbol{C}$. betacea seedlings. For the stems, leaves and shoots of $C$. betacea seedlings, mulching with accumulator plants straws could increase its total potassium content in varying degress compared with the uncovered (Table 2). The order of roots total potassium content in $C$. betacea seedlings from large to small was ranked: $S$. media, uncovered, $T$. repens, E. prostrata, $C$. canadensis. And mulching with $S$. media straw increased the total potassium content of the roots in $C$. betacea seedlings by $42.61 \%(P<0.05)$ compared with the uncovered. The order of stems total potassium content in $C$. betacea seedlings from large to small were all ranked: $S$. media, E. 
prostrata, $T$. repens, $C$. canadensis, uncovered. And mulching with $S$. media straw increased the total potassium content of the stems in $C$. betacea seedlings by $144.23 \%(P<0.05)$ compared with the uncovered. The order of leaves total potassium content in $C$. betacea seedlings from large to small was ranked: $S$. media, E. prostrata, $C$. canadensis, $T$. repens, uncovered. And mulching with $S$. media straw increased the total potassium content of the leaves in $C$. betacea seedlings by $109.64 \%(P<0.05)$ compared with the uncovered. The order of leaves total potassium content in $C$. betacea seedlings from large to small was ranked: S. media, E. prostrata, C. canadensis, T. repens, uncovered. And mulching with $S$. media straw increased the total potassium content of the shoots in $C$. betacea seedlings by $119.03 \%(P<0.05)$ compared with the uncovered.

Table 1 Total phosphorus content in C. betacea seedlings

\begin{tabular}{|c|c|c|c|c|}
\hline Cd accumulate plant straw & $\begin{array}{c}\text { Roots } \\
(\mathrm{g} / \mathrm{kg})\end{array}$ & $\begin{array}{c}\text { Stems } \\
(\mathrm{g} / \mathrm{kg})\end{array}$ & $\begin{array}{c}\text { Leaves } \\
(\mathrm{g} / \mathrm{kg})\end{array}$ & $\begin{array}{c}\text { Shoots } \\
(\mathrm{g} / \mathrm{kg})\end{array}$ \\
\hline Uncovered & $0.244 \pm 0.004 \mathrm{~d}$ & $0.206 \pm 0.007 \mathrm{~d}$ & $0.373 \pm 0.017 \mathrm{~d}$ & $0.320 \pm 0.012 \mathrm{~d}$ \\
\hline T. repens & $0.245 \pm 0.014 \mathrm{~d}$ & $0.256 \pm 0.012 \mathrm{c}$ & $0.389 \pm 0.034 \mathrm{~d}$ & $0.344 \pm 0.023 \mathrm{~d}$ \\
\hline E. prostrata & $0.291 \pm 0.022 \mathrm{c}$ & $0.269 \pm 0.021 \mathrm{~b}$ & $0.449 \pm 0.028 \mathrm{c}$ & $0.389 \pm 0.036 \mathrm{c}$ \\
\hline C. canadensis & $0.320 \pm 0.018 \mathrm{~b}$ & $0.270 \pm 0.016 \mathrm{~b}$ & $0.494 \pm 0.043 \mathrm{~b}$ & $0.418 \pm 0.041 \mathrm{~b}$ \\
\hline S. media & $0.412 \pm 0.032 \mathrm{a}$ & $0.595 \pm 0.043 \mathrm{a}$ & $0.642 \pm 0.035 \mathrm{a}$ & $0.627 \pm 0.052 \mathrm{a}$ \\
\hline
\end{tabular}

Values are means \pm standard errors. Means with the same letter within each column are not significantly different at $p<0.05$.

Table 2 Total potassium content in C. betacea seedlings

\begin{tabular}{|c|c|c|c|c|}
\hline Cd accumulate plant straw & $\begin{array}{c}\text { Roots } \\
(\mathrm{g} / \mathrm{kg})\end{array}$ & $\begin{array}{c}\text { Stems } \\
(\mathrm{g} / \mathrm{kg})\end{array}$ & $\begin{array}{c}\text { Leaves } \\
(\mathrm{g} / \mathrm{kg})\end{array}$ & $\begin{array}{c}\text { Shoots } \\
(\mathrm{g} / \mathrm{kg})\end{array}$ \\
\hline Uncovered & $28.30 \pm 0.77 \mathrm{~b}$ & $18.56 \pm 0.64 \mathrm{c}$ & $22.92 \pm 0.78 \mathrm{~d}$ & $21.54 \pm 0.45 \mathrm{~d}$ \\
\hline T. repens & $27.76 \pm 0.45 \mathrm{~b}$ & $21.08 \pm 1.28 \mathrm{~b}$ & $30.54 \pm 0.75 \mathrm{c}$ & $27.37 \pm 0.63 \mathrm{c}$ \\
\hline E. prostrata & $27.03 \pm 0.72 \mathrm{~b}$ & $21.88 \pm 0.55 \mathrm{~b}$ & $37.58 \pm 0.69 \mathrm{~b}$ & $32.34 \pm 1.22 \mathrm{~b}$ \\
\hline C. canadensis & $21.94 \pm 0.41 \mathrm{c}$ & $20.78 \pm 0.49 \mathrm{bc}$ & $36.86 \pm 0.82 \mathrm{~b}$ & $31.41 \pm 0.65 \mathrm{~b}$ \\
\hline S. media & $40.36 \pm 2.13 \mathrm{a}$ & $45.33 \pm 2.61 \mathrm{a}$ & $48.05 \pm 1.76 \mathrm{a}$ & $47.18 \pm 1.26 \mathrm{a}$ \\
\hline
\end{tabular}

Values are means \pm standard errors. Means with the same letter within each column are not significantly different at $p<0.05$.

\section{Conclusions}

In cadmium contaminated soil, planted $C$. betacea after mulching with $T$. repens, Eclipta prostrate, C. canadensis, $S$. media straws could affect the content of total phosphorus and total potassium in $C$. betacea seedlings. For the content of total phosphorus in all parts of $C$. betacea seedlings, all accumulator plants straws could improve the total phosphorus content in $C$. betacea seedlings. Among all treatments, mulching with E. prostrate, $C$. Canadensis and $S$. media straws could significantly increase the content of total phosphorus in roots, stems, leaves and shoots of $C$. betacea seedlings. And mulching with $S$. media straw maximized the total phosphorus content in all parts of $C$. betacea seedlings. For the content of total potassium in leaves and shoots of $C$. betacea seedlings, all accumulator plants straws could significantly increase the total potassium content in $C$. betacea seedlings. And the content of total potassium in leaves and shoots of $C$. betacea seedlings was significantly higher than other treatments by mulching with $S$. media straw. For the total 
potassium content of the roots in $C$. betacea seedlings, only mulching with $S$. media straw significantly increased the content of total potassium in $C$. betacea seedlings. In addition, mulching with $T$. repens, $E$. prostrate and $S$. media straws all significantly increased the total potassium content of the stems in $C$. betacea seedlings. And the total potassium content of the stems in $C$. betacea seedlings was highest in all treatments by mulching with $S$. media straw. These results indicated that only mulching with $S$. media straw could significantly increase the total phosphorus and total potassium content in all parts of $C$. betacea seedlings in Cd-contaminated soil. Therefore, mulching with $S$. media straw could significantly promote the nutrients uptake of $C$. betacea seedlings under Cd stress.

\section{Acknowledgements}

This work was financially supported by the Application Infrastructure Project of Science and Technology Department of Sichuan Province (2016JY0258).

\section{References}

[1] Y.X. Su, S.J. Wang, L.W. Zhao and Q.B. Chen: Tianjin Agricultural Sciences Vol. 22(2016), p. 20.

[2] P. Yu, F. Gao, J. Liu, Q. Liang, Y.Y. Han, J.X. Wang and Y.H. Jia: Chinese Agricultural Science Bulletin Vol. 33(2017), p. 89.

[3] X.S. Han, C.Y. Cao, J.D. Yao and F.F. Gao: Chinese Journal of Ecology Vol. 28(2009), p. 2250 .

[4] J. Zhang, X.X. Wen, Y.C. Liao and Y. Liu: Plant Nutrition and Fertilizer Science Vol. 16(2010), p. 612.

[5] G.W. Xu, L.N.Yang, Z.Q. Wang, L.J. Liu and J.C. Yang: Acta Agronomica Sinica Vol. 34(2008), p. 1424.

[6] L.J. Lin, D.Y. Yang, F.Y. Tang, L. Luo, M. A. Liao and L. Yuan: Chinese Journal of Soil Science Vol. 46(2015), p. 483.

[7] S. Zhi, Y.X. Wu, Y. J. Wang, H. Wang and Z.X. Huang: Hubei Agricultural Sciences Vol. 53(2014), p. 5880.

[8] J. He, L.J. Lin, J, Shi, Y.M. Tan, Q.Q. Ma, C.Y. Liu, K. Wen, J.J. Huang, C.C. Zhong and M.A. Liao: Chinese Journal of Soil Science Vol. 47(2016), p. 1259.

[9] G. Bidar, G. Garçon, C. Pruvot, D. Dewaele, F. Cazier, F. Douay and P. Shirali: Environmental Pollution Vol. 147(2007), p. 546.

[10]L. Luo, L.J. Lin, M.A. Liao, X. Zhang and D.Y. Yang: Acta Agriculturae Boreali-Sinica Vol. 29(2014). p. 216.

[11]S.H. Wei, Q. X. Zhou, U. K. Saha, H. Xiao, Y.H. Hu, L.P. Ren and G. Ping: Journal of Hazardous Materials Vol. 163(2009), p. 32.

[12]L.J. Lin, B. Ning, M. A. Liao, H.J. Lan and H. Liang: Ecology and Environmental Sciences Vol. 23(2014), p. 673.

[13]S.D. Bao: Agrochemical Soil Analysis (3rd edition, China Agriculture Press, Beijing, China 2000). 